\title{
DEVELOPMENT OF A DECISION MODEL TO PRIORITIZING POTENTIAL FRAUD CASES FOR INTERNAL INVESTIGATIVE PURPOSES
}

\author{
James Carroll \\ Carlow University \\ Pittsburgh, PA, USA \\ E-mail: jacarrol12939@carlow.edu \\ Enrique $\mathrm{Mu}$ \\ Carlow University \\ Pittsburgh, PA, USA \\ E-mail:muex@carlow.edu
}

\begin{abstract}
Corporate Fraud Investigation Units receive dozens of reports about possible fraud allegations annually. While all allegations must be addressed, clearly, it is not possible to investigate all cases upon receipt due to resource limitations, thus a method is necessary determine the cases to allocate resources and address immediately. For this reason, this study will develop an AHP ratings model for the prioritization of alleged fraud reports in a corporate setting, more specifically in a large metals and mining manufacturing company.
\end{abstract}

Keywords: Fraud Investigation, Fraud Prioritization, Fraud Management, Internal Investigation Prioritization, Corporate Investigation, Internal Investigation. 


\section{Introduction}

By developing a model that encompasses a rational, thorough risk-based approach and applying it to internal investigations of reported or identified misconduct, the investigative unit(s) within an organization will improve their efficiency and effectiveness and usage of resources because the highest rated cases will be investigated first. Furthermore, by applying a model based on static criteria, a more defensible position can be established as to why certain investigations are pursued before others, thereby lessening the claims of disparate treatment or the pursuit of a "witch hunt", whether perceived or real, based on internal politics.

\section{Literature Review}

A review of current literature related to the topic of internal fraud investigation case prioritization resulted in the discovery of limited materials focusing on this topic. Many of the contemporary writings focus on the assessment and usage of various factors in assessing fraud risk, thus the topic of fraud risk will be explored to determine the potential of adopting a fraud risk assessment model to prioritize reports of internal fraud.

The literature directly related to the prioritization of internal fraud investigations described two different methods. Wilhelm (2004) conducted a study assessing a holistic approach to fraud management and addressed issues and suggestions related to case prioritization (p.23). Wilhem (2004) further identifies that tracking cases by fraud type, recoveries, and other characteristics along with aggregating and linking like cases allow for improve prioritization of cases. However, Wilhelm (2004) does not explore this topic further by providing an assessment technique or methodology to provide for efficient usage of investigation resources.

Grimstad (2007) issued a report on a review of the investigation division of the United Nations (UN), which include an assessment and review of the case prioritization model, Risk Assessment Profile (RAP). Grimstad (2007) notes that the RAP score determines the priority of the case, is based on nine specific criteria, which once assessed if the score is below 100-point threshold the case is not investigated, and 15-20 assessments are completed per week (p.32-34). However, the point difference is quite arbitrary and whether it can be applied to all institutions is very questionable.

Our review of the literature shows the use of subjective expert judgment (Wilhelm 2004) or a methodology with a very arbitrary criteria weighting (Grimstad 2007) and little scientific foundation. Also, a quick check with about half dozen colleagues in other institutions suggests that many investigators prioritize their cases based on gut feeling. For this reason, rather than trying to develop a universal model of case investigation prioritization, we decided to focus on developing a prioritization model for our target firm using criteria consistent with the existing corporate policies.

\section{Hypotheses/Objectives}

The goal of this study is to develop an Analytic Hierarchical Process (AHP) Ratings Model for the Prioritization of Potential Fraud Cases in the target firm for this case. 
Existing policies will be used to develop the criteria and their weights.

\section{Research Design/Methodology}

An AHP ratings model has been developed for the prioritization of potential financial fraud cases in the specific setting of this organization using the Super Decisions software. For this reason, the main sources for factors and weight judgments were obtained from experts within the institution. The evaluation factors and importance weight assessment has been developed by James Carroll (co-author) an expert fraud investigator at a large metals and manufacturing company who was the leading subject matter expert for the development of the model. The AHP decision facilitation process and analysis was led by Enrique $\mathrm{Mu}$ (co-author), Professor of Fraud and Forensics Research and AHP methodological expert, to ensure model development according to AHP best practices. The final model will be validated by the personnel of the internal audit fraud investigation team with some case evaluations.

\section{Data/Model Analysis}

The Decision model (Figure 1) and testing in actual cases (Table 1) are shown below: 


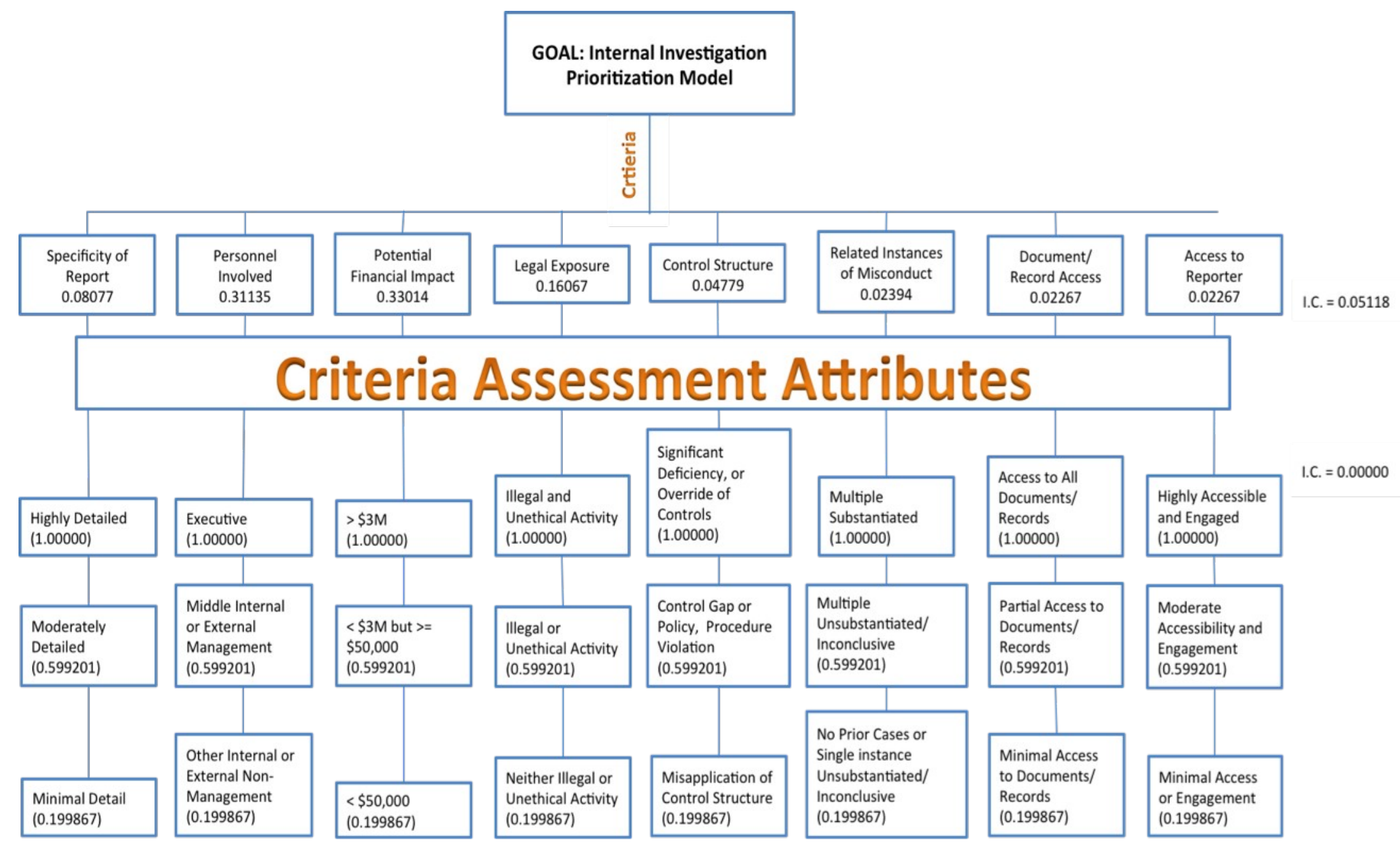

Figure 1 - Investigative Case Prioritization Model 
Table 1 - Using an AHP Ratings Model to Prioritize Alleged Fraud

\begin{tabular}{|c|c|c|c|c|c|c|c|c|c|c|}
\hline & Priorities & Totals & $\begin{array}{r}\text { Specificity } \\
\text { of Report }\end{array}$ & $\begin{array}{c}\text { Personnel } \\
\text { Involved }\end{array}$ & $\begin{array}{c}\text { Potential } \\
\text { Financial } \\
\text { Impact } \\
\end{array}$ & $\begin{array}{c}\text { Legal } \\
\text { Exposure } \\
\end{array}$ & Control Structure & $\begin{array}{c}\text { Related } \\
\text { Instances of } \\
\text { Misconduct } \\
\end{array}$ & $\begin{array}{c}\text { Document/ } \\
\text { Record } \\
\text { Access } \\
\end{array}$ & $\begin{array}{l}\text { Access to } \\
\text { Reporter }\end{array}$ \\
\hline Ideal & 0.236014 & 1.000000 & $\begin{array}{l}\text { Highly } \\
\text { Detailed }\end{array}$ & Executive & $>\$ 3 \mathrm{M}$ & $\begin{array}{l}\text { Illegal and } \\
\text { Unethical }\end{array}$ & $\begin{array}{c}\text { Significant } \\
\text { Deficiency or } \\
\text { Override of Controls }\end{array}$ & $\begin{array}{c}\text { Multiple } \\
\text { Substantiated }\end{array}$ & $\begin{array}{l}\text { Access to all } \\
\text { Documents/ } \\
\text { Records }\end{array}$ & $\begin{array}{c}\text { Highly } \\
\text { Accessible } \\
\text { and Engaged }\end{array}$ \\
\hline Case1 & 0.175280 & 0.742668 & $\begin{array}{l}\text { Moderately } \\
\text { Detailed }\end{array}$ & Executive & $\begin{array}{l}<\$ 3 \mathrm{M} \text { but } \\
>=\$ 50 \mathrm{~K}\end{array}$ & $\begin{array}{l}\text { Illegal or } \\
\text { Unethical }\end{array}$ & $\begin{array}{l}\text { Control Gap or } \\
\text { Policy or Procedure } \\
\text { Violation }\end{array}$ & $\begin{array}{c}\text { Multiple } \\
\text { Substantiated }\end{array}$ & $\begin{array}{l}\text { Access to all } \\
\text { Documents/ } \\
\text { Records }\end{array}$ & $\begin{array}{l}\text { Moderately } \\
\text { Accessible } \\
\text { and Engaged }\end{array}$ \\
\hline Case2 & 0.145941 & 0.618357 & $\begin{array}{l}\text { Moderately } \\
\text { Detailed }\end{array}$ & $\begin{array}{l}\text { Middle } \\
\text { Mgt }\end{array}$ & $\begin{array}{l}<\$ 3 \mathrm{M} \text { but } \\
>=\$ 50 \mathrm{~K}\end{array}$ & $\begin{array}{l}\text { Illegal or } \\
\text { Unethical }\end{array}$ & $\begin{array}{c}\text { Significant } \\
\text { Deficiency or } \\
\text { Override of Controls }\end{array}$ & $\begin{array}{c}\text { Multiple } \\
\text { Unsubstantiated } \\
\text { /Inconclusive }\end{array}$ & $\begin{array}{c}\text { Partial } \\
\text { Document/ } \\
\text { Record } \\
\text { Access } \\
\end{array}$ & $\begin{array}{l}\text { Moderately } \\
\text { Accessible } \\
\text { and Engaged }\end{array}$ \\
\hline Case 3 & 0.157500 & 0.667333 & $\begin{array}{l}\text { Highly } \\
\text { Detailed }\end{array}$ & $\begin{array}{c}\text { Other } \\
\text { Internal or } \\
\text { External } \\
\text { Party } \\
\end{array}$ & $>\$ 3 \mathrm{M}$ & $\begin{array}{l}\text { Illegal or } \\
\text { Unethical }\end{array}$ & $\begin{array}{c}\text { Significant } \\
\text { Deficiency or } \\
\text { Override of Controls }\end{array}$ & $\begin{array}{l}\text { No Prior } \\
\text { Instances }\end{array}$ & $\begin{array}{l}\text { Access to all } \\
\text { Documents/ } \\
\text { Records }\end{array}$ & $\begin{array}{c}\text { Highly } \\
\text { Accessible } \\
\text { and Engaged }\end{array}$ \\
\hline Case4 & 0.162020 & 0.686485 & $\begin{array}{l}\text { Highly } \\
\text { Detailed }\end{array}$ & $\begin{array}{c}\text { Other } \\
\text { Internal or } \\
\text { External } \\
\text { Party } \\
\end{array}$ & $>\$ 3 \mathrm{M}$ & $\begin{array}{l}\text { Illegal or } \\
\text { Unethical }\end{array}$ & $\begin{array}{c}\text { Significant } \\
\text { Deficiency or } \\
\text { Override of Controls }\end{array}$ & $\begin{array}{c}\text { Multiple } \\
\text { Substantiated }\end{array}$ & $\begin{array}{l}\text { Access to all } \\
\text { Documents/ } \\
\text { Records }\end{array}$ & $\begin{array}{c}\text { Highly } \\
\text { Accessible } \\
\text { and Engaged }\end{array}$ \\
\hline Case5 & 0.123246 & 0.522199 & $\begin{array}{c}\text { Minimal } \\
\text { Detail }\end{array}$ & Executive & $<\$ 50 \mathrm{~K}$ & $\begin{array}{l}\text { Illegal or } \\
\text { Unethical }\end{array}$ & $\begin{array}{l}\text { Misapplication of } \\
\text { Control Structure }\end{array}$ & $\begin{array}{l}\text { No Prior } \\
\text { Instances }\end{array}$ & $\begin{array}{l}\text { Partial } \\
\text { Document/ } \\
\text { Record } \\
\text { Access }\end{array}$ & $\begin{array}{c}\text { Minimal } \\
\text { Access and } \\
\text { Engagement }\end{array}$ \\
\hline
\end{tabular}




\section{Limitations}

While the application of the AHP methodology will introduce a level of objectivity into the model, the lack of criteria with objective measures can also be a limitation on the use of the model. However, this can be mitigated by requesting team members of the investigation unit to make their own independent evaluation and aggregating the final scores to obtain the team evaluation ratings. Related to the model criteria, the number and weighting of the criteria are primarily based on the experience of the company experts where the model will be used. Additional validation is provided by the fraud risk assessment factors discussed in the Fraud Examiners Manual.

\section{Conclusions}

The fraud allegation case prioritization model develop herein provide corporate investigation units in our target firm a means by which they can produce a rational, defensible argument when question, internally or eternally, as to why certain fraud cases were address before others regardless of timing. Also, given the large number of investigation requests (ranging in the order of dozens), this model provides a way to quickly address the most important cases; that is, those with potential to cause serious damage to the company if not addressed quickly. One important item any practitioner employing this model must consider and plan for is the model will require the constant reshuffling of case priorities, otherwise the effectiveness and logic will be diminished because while cases would be assessed and assigned a priority value, case would to some extent be being addressed on a first-in, first-out method. Also, this model developed was developed due to the need to prioritize 40-50 cases annually, and has thus provided the ability to focus investigations to the most significant issues. Throughout the course of researching prioritization models currently employed there was significant difficultly identifying fraud allegation case prioritization models in practice or developed for corporate environments. More extensive research needs to be completed on this topic because investigation resources within corporate environments are limited and effective methodologies such as the one introduced here need to validated and available so that corporate investigators can better determine where to focus their attention.]

\section{Key References}

Grimstad, E. (2007). Final Report: Review of the OIOS Investigations Division, United Nations. Retrieved from http://www.innercitypress.com/oiosrev1.pdf.

Wilhelm, W. K. (2004). The Fraud Management Lifecycle Theory: A Holistic Approach to Fraud Management. Journal of Economic Crime Management 2(2), p.1-38. Retrieved from https://library.utica.edu/academic/institutes/ecii/publications/articles/BA309CD201B6-DA6B-5F1DD7850BF6EE22.pdf.

\section{Appendices}

Appendix 1: Criteria Definition for Prioritization Model (To be included in full paper). 